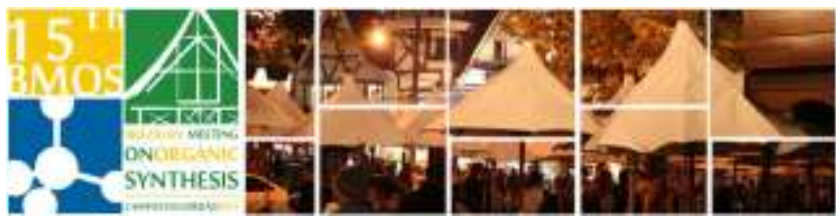

\title{
Silica-Supported Prolyl Pseudo-Peptide Organocatalysts: Application in the Direct Asymmetric Michael Addition
}

\author{
Gabriel dos S. Scatena; Alexander F. De la Torre, Quezia B. Cass, Márcio W. Paixão \\ *gabrielscatena@hotmail.com
}

Keywords: silica supported catalyst; Ugi Reaction; organocatalysis;

\section{INTRODUCTION}

Organocatalysis is represented by a set of broadly applicable and efficient synthetic tools for the preparation of many types of enantiomerically enriched molecules. In this regard, L-proline and related derivatives have risen to prominence since List, Barbas and Lerner rediscovered that these small molecules could stereoselectively catalyze reactions without the requirement of transition metals. Chiral organocatalysts used in stereoselective reactions are usually nontoxic, highly efficient and selective and readily available. However, the preparation of more complex organocatalysts may involve several steps. Therefore, in an economic and environmental perspective, the easy recovery and recycling of the catalyst remain a significant challenge. One of the most widely used strategies for this purpose consists in immobilizing the homogeneous catalyst on silica. This hybrid material, have the advantages of easy handling, recovery and reuse of the catalyst. ${ }^{[1]}$ In connection with our ongoing research program into the design of new class of organocatalyst, we recently developed a new prolyl pseudo-peptide by a multicomponent approach. Inspired by these results, we further employed this strategy for the synthesis of a supported organocatalysts.

\section{RESULTS AND DISCUSSION}

The organocatalyst was easily obtained by Ugi-4C reaction using paraformaldehyde, cyclohexyl isonitrile, Boc-proline and aminopropyl silica (Luna $2.35 \mathrm{mmol} / \mathrm{g}$ of silica) in methanol. Furthermore, the Boc group deprotection was done at $95^{\circ} \mathrm{C}$ under reduced pressure (Figure 1).

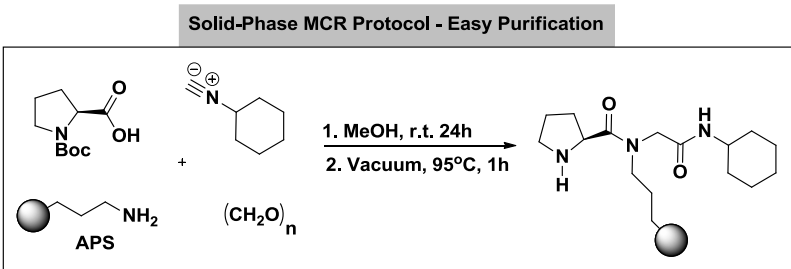

Figure 1. Solid-phase Ugi-4C reaction: Synthesis of an immobilized organocatalyst .

The solid-phase multicomponent approach was also evaluated under different stoichiometry of reagents- based on the amount of amino group presented in silica (Table 1)

Table 1. Screening of loading of organocatalyst in silica.

\begin{tabular}{ccc}
\hline Cat & Equivalents $^{\mathbf{a}}$ & Loading $_{(\mathrm{mmol} / \mathbf{g} \text { of silica) }} \mathbf{b}^{\mathbf{2}}$ \\
\hline Cat 1 & 0.25 & 0.18 \\
Cat 2 & 0.50 & 0.20 \\
Cat 3 & 1.00 & 0.23 \\
Cat 4 & 2.00 & 0.24 \\
Cat 5 & 4.00 & 0.21
\end{tabular}

Reaction conditions: Aminopropilsilica (100 mg; $0.235 \mathrm{mmol}$ of $\mathrm{NH}_{2}$ ), paraformaldehyde, cyclohexilisonitrile, (S)-Boc-proline in methanol $(500 \mu \mathrm{l})$ for $24 \mathrm{~h}$ at r.t. ${ }^{a}$ Equivalents of reagents relative to amino group in silica ${ }^{\mathrm{b}}$ Based on the quantity of Nitrogen in CHNS.

The catalytic behavior of these new materials was examined on the asymmetric addition of butyraldehyde to $\beta$-nitrostyrene. As a result, promising diastereo- and enantioselectivities were obtained using catalyst 3 .

Table 2. Asymmetric Catalytic Addition of Butyraldehyde to $\beta$-nitrostyrene ${ }^{a}$

\begin{tabular}{cccc} 
Catalyst & Conversion (\%) & $\mathbf{d r}^{\mathbf{6}}$ & ee (\%) \\
\hline Silica & 0 & 0 & Catalyst $\mathbf{3 ~ m o l} \%$ \\
APS & 40 & $80 / 20$ & 0 \\
Cat 1 & 23 & $86 / 14$ & 35 \\
Cat 3 & 55 & $93 / 07$ & 73 \\
Cat 5 & 5 & $87 / 13$ & 57
\end{tabular}

Reaction conditions: Butyraldehyde ( 3 equiv.) and trans- $\beta$-nitrostyrene $(1$ equiv.) and $3 \mathrm{~mol} \%$ of catalyst in toluene $(0.2 \mathrm{~mL})$ for $24 \mathrm{~h}$ at $8^{\circ} \mathrm{C}$. ${ }^{\mathrm{b}}$ Determined by chiral stationary phase HPLC on the syn diastereoisomer.

\section{CONCLUSION}

A new class of supported organocatalyst was successfully synthetized by using a one-pot Ugi-4C reaction. Encouraging results were obtained on the asymmetric Michael addition of butyraldehyde to $\beta$ nitrostyrene.

\section{ACKNOWLEDGEMENTS}

FAPESP (09/07281-0), CNPq and CAPES.

\section{REFERENCES}

1 Bortolini, O., Cavazzini, A., Giovannini, P. P., Greco, R., Marchetti, N., Massi, A. and Pasti, L., Chem. Eur. J., 2013, 19, 7802-7808. 